ISSN: 2052-5206

journals.iucr.org/b

\title{
Could incommensurability in sulfosalts be more common than thought? The case of meneghinite, $\mathrm{CuPb}_{13} \mathrm{Sb}_{7} \mathrm{~S}_{24}$
}

\section{Luca Bindi, Václav Petř́íček, Cristian Biagioni, Jakub Plášil and Yves Moëlo}

Acta Cryst. (2017). B73, 369-376

\section{IUCr Journals CRYSTALLOGRAPHY JOURNALS ONLINE \\ Copyright (C) International Union of Crystallography \\ Author(s) of this paper may load this reprint on their own web site or institutional repository provided that this cover page is retained. Republication of this article or its storage in electronic databases other than as specified above is not permitted without prior permission in writing from the IUCr. \\ For further information see http://journals.iucr.org/services/authorrights.html}




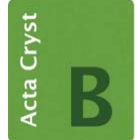

STRUCTURAL SCIENCE CRYSTAL ENGINEERING MATERIALS

ISSN 2052-5206

Received 24 December 2016

Accepted 15 February 2017

Edited by A. Katrusiak, Adam Mickiewicz University, Poland

Keywords: meneghinite; crystal structure; incommensurability; sulfosalt.

CCDC reference: 1533002

B-IncStrDB reference: 13202EGzpbl

Supporting information: this article has supporting information at journals.iucr.org/b

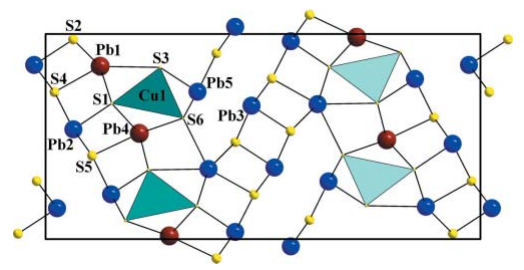

C 2017 International Union of Crystallography

\section{Could incommensurability in sulfosalts be more common than thought? The case of meneghinite, $\mathrm{CuPb}_{13} \mathrm{Sb}_{7} \mathrm{~S}_{24}$}

\author{
Luca Bindi, ${ }^{a}$ Václav Petř́čck, ${ }^{b}$ Cristian Biagioni, ${ }^{c *}$ Jakub Plášil ${ }^{\mathrm{b}}$ and Yves Moëlo ${ }^{\mathrm{d}}$
}

${ }^{\mathbf{a}}$ Dipartimento di Scienze della Terra, Università di Firenze, Via La Pira 4, I-50121 Firenze, Italy, ${ }^{\mathbf{b}}$ Institute of Physics, ASCR, Na Slovance 2, 18221 Praha 6, Czech Republic, 'Dipartimento di Scienze della Terra, Università di Pisa, Via Santa Maria 53, I-56126 Pisa, Italy, and Institut des Matériaux Jean Rouxel, UMR 6502, CNRS, Université de Nantes, 2 rue de la Houssinière, 44322 Nantes CEDEX 3, France. *Correspondence e-mail: biagioni@dst.unipi.it

The structure of meneghinite $\left(\mathrm{CuPb}_{13} \mathrm{Sb}_{7} \mathrm{~S}_{24}\right)$, from the Bottino mine in the Apuan Alps (Italy), has been solved and refined as an incommensurate structure in four-dimensional superspace. The structure is orthorhombic, superspace

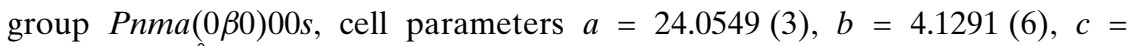
11.3361 (16) $\AA$, modulation vector $\mathbf{q}=0.5433$ (4) b*. The structure was refined from 6604 reflections to a final $R=0.0479$. The model includes modulation of both atomic positions and displacement parameters, as well as occupational waves. The driving forces stabilizing the modulated structure of meneghinite are linked to the occupation modulation of $\mathrm{Cu}$ and some of the $\mathrm{Pb}$ atoms. As a consequence of the $\mathrm{Cu} /[]$ and $\mathrm{Pb} / \mathrm{Sb}$ modulations, three- to sevenfold coordinations of the $M$ cations $(\mathrm{Pb} / \mathrm{Sb})$ occur in different parts of the structure. The almost bimodal distribution of the occupation of $\mathrm{Cu} /[]$ and $\mathrm{Pb} / \mathrm{Sb}$ at $M 5$ conforms with the coupled substitution $\mathrm{Sb}^{3+}+[] \rightarrow \mathrm{Pb}^{2+}+\mathrm{Cu}^{+}$, thus corroborating the hypothesis deduced previously for the incorporation of copper in the meneghinite structure. The very small departure $(\sim 0.54$ versus 0.50 ) from the commensurate value of the modulation raises the question of whether other sulfosalts considered superstructures have been properly described, and, in this light, if incommensurate modulation in sulfosalts could be much more common than thought.

\section{Introduction}

The recent development of aperiodic crystallography has led to the discovery of several incommensurate crystals, and indicated that incommensurability cannot be neglected in any field of solid-state chemistry. Indeed, incommensurate modulation has been found in almost all different families of structures that include synthetic inorganic and organic compounds, as well as proteins (Janssen et al., 2007; van Smaalen, 2007). Modulated structures have also been widely found in various minerals, although their structural analysis is still strongly underdeveloped. Indeed, it is not common to find minerals with strong and sharp satellites related to an aperiodic structure to be used for a structural refinement with superspace formalism. Nevertheless, there are several minerals which have incommensurate satellites visible with electron diffraction including: clinopyroxenes (kosmochlordiopside join; Sakamoto et al., 2003), quartz (e.g. Heaney \& Veblen, 1991), feldspars (e.g. Yamamoto et al., 1984; Steurer \& Jagodzinski, 1988; Kalning et al., 1997; Sanchez-Munoz et al., 1998), melilite (Bindi et al., 2001, and references therein), fresnoite (Bindi et al., 2006), cancrinite-sodalite join (e.g. Hassan \& Buseck, 1989, 1992; Xu \& Veblen, 1995; Hassan, 
2000; Hassan et al., 2004; Bolotina, 2006; Bolotina et al., 2006), nepheline (Withers et al., 1998; Angel et al., 2008; Friese et al., 2011), lazurite (Rastsvetaeva et al., 2002; Bolotina et al., 2003a, $2003 b$, 2004), tridymite (e.g. Pryde \& Dove, 1998) and mullite (Angel et al., 1991). Incommensurate modulations can also be found among sulfides, tellurides and sulfosalts including bornite (Buseck \& Cowley, 1983), pyrrhotite (Li \& Franzen, 1996), calaverite (e.g. Schutte \& de Boer, 1988; Caracas \& Gonze, 2001), sylvanite (Krutzen \& Inglesfield, 1990), rickardite (Schutte \& de Boer, 1993), muthmannite (Bindi, 2008), proustite (Subramanian et al., 2000), the cylindrite-franckeite series (Evain et al., 2006; Makovicky et al., 2008, 2011), lengenbachite (Makovicky \& Hyde, 1981; Makovicky et al., 1994), the pearceite-polybasite series (Withers et al., 2008; Bindi et al., 2013), and sartorite (Pring et al., 1993). Among sulfosalts, however, only the incommensurate structures of levyclaudite (Evain et al., 2006) and franckeite (Makovicky et al., 2011) have been studied by means of a multidimensional crystal structure refinement. The paucity of these studies, together with the fact that sulfosalts are widespread in nature, could hide some heretofore unknown structural complexities.

Sulfosalts are complex chalcogenides with the formula $A_{x} B_{y} C_{z}$, where $A=\mathrm{Pb}, \mathrm{Cu}, \mathrm{Ag}, \mathrm{Hg}, \mathrm{Tl}, \mathrm{Fe}, \mathrm{Mn}, \mathrm{Sn}^{2+}, \mathrm{Sn}^{4+}$ and other metals, $B=\mathrm{As}$, Sb and $\mathrm{Bi}$ in fundamentally threefold coordination, and $C=\mathrm{S}^{2-}, \mathrm{Se}^{2-}$ and $\mathrm{Te}^{2-}$ (Makovicky, 1997). Their crystal structures can be described as formed by rods, blocks or layers of simple archetypal structures (e.g. PbS, $\mathrm{SnS}$ ) variously recombined. Among the SnS-archetype-based sulfosalts, the members of the accretional homologous series of meneghinite (Makovicky, 1985) exhibit a crystal structure made up of slices of SnS-like structure. Aikinite $\left(\mathrm{CuPbBiS}_{3}\right.$; Chapman, 1843) and meneghinite $\left(\mathrm{CuPb}_{13} \mathrm{Sb}_{7} \mathrm{~S}_{24} ; \mathrm{Bechi}, 1852\right)$ are the oldest members of this series, and were always described with a unit cell having one of the crystallographic axes of about $4 \AA$. The unit cell of most SnS-archetype- and $\mathrm{PbS}$-archetype-based sulfosalts is characterized by such a periodicity that can be commonly found doubled, giving rise to $8 \AA$ commensurate superstructures.

The crystal structure of meneghinite was solved by Euler \& Hellner (1960) using a sample from the Bottino mine (Tuscany, Italy). These authors were able to solve only the $4 \AA$ structure, observing the occurrence in the oscillation photographs of very faint layer lines between the zero line and the strong line representing the $4.128 \AA$ A periodicity. According to these authors, the actual superstructure of meneghinite should have a $24 \times 4.128 \AA$ periodicity and the weak layer lines could correspond to the 11th and 13th order of reflections. As a matter of fact, with very long exposures they were not able to find any of the missing layer lines. Similar features were reported by Hicks \& Nuffield (1978) in meneghinite from Ontario, Canada. In contrast, $\mathrm{Cu}$-free synthetic meneghinite did not show any additional superstructure reflections. According to Hicks \& Nuffield (1978), the appearance of the faint layer lines results from some ordering of $\mathrm{Pb}$ and $\mathrm{Sb}$. Finally, Moëlo et al. (2002) reported a chemical and structural study of a Cu-poor meneghinite from La Lauzière Massif (Savoie, France). These authors refined the crystal structure in the same orthorhombic symmetry (space group Pnma) and with the same unit cell $[a=24.080(5), b=4.1276(8), c=$ 11.369 (2) $\left.\AA, V=1130.0(4) \AA^{3}, Z=4\right]$ as Euler \& Hellner (1960), but showed a significantly lower site-occupancy factor for the tetrahedral $\mathrm{Cu}$ site $(0.146$ versus 0.25$)$.

Here we report the finding of a meneghinite crystal with additional weak reflections leading to an apparent doubling of the $4 \AA$ periodicity. A careful inspection of the position of the additional reflections indicated that they are actually incommensurate with the lattice periodicity (being slightly displaced from the $\frac{1}{2}$ position) (Fig. 1); these reflections correspond to the layer lines described by Euler \& Hellner (1960) and Hicks \& Nuffield (1978) and interpreted as due to a commensurate superstructure. The very small departure $(\sim 0.54$ versus 0.50$)$ from the commensurate value raises the question: could several sulfosalts previously considered superstructures have been properly solved and refined? Indeed, even if the $8 \AA$ periodicity is a natural consequence of the trapezoidal cross sections of many As-, Sb- and sometimes Bi-coordination polyhedra, more complex superstructures are commonly reported for the minerals of the sulfosalt realm. These could indeed represent only approximations and the problems usually encountered in their solutions/refinements (e.g. partially occupied sites, structural disorder, large displacement parameters) could be due to the fact that the structure was forced to be commensurate.

\section{Experimental}

\subsection{Sample occurrence and chemical data}

The sample of meneghinite used in the present study is from the $\mathrm{Pb}-\mathrm{Zn}-\mathrm{Ag}$ Bottino mine in the Apuan Alps (Tuscany, Italy). The sample was represented by a loose crystal, $2 \mathrm{~cm}$ in length and $1 \mathrm{~cm}$ in thickness, collected in 2005 from the Redola level, one of the ancient mining works of the mine. Meneghinite occurred in a vug of a quartz vein, in association with chalcopyrite, Fe-bearing dolomite and siderite.

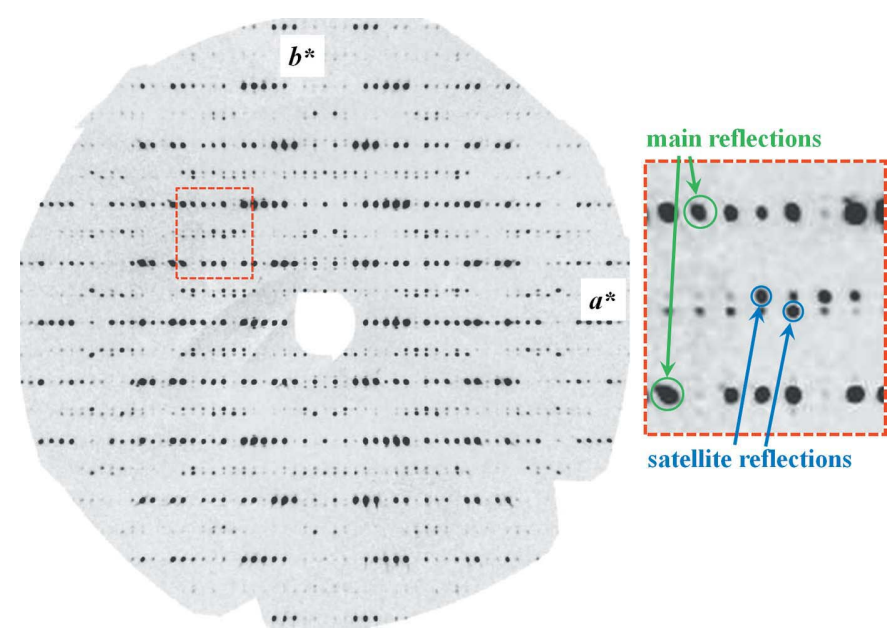

Figure 1

Reconstructed precession photograph on $h k \overline{2}$ reciprocal lattice layer for meneghinite. Main and satellite reflections are indicated in the inset. 
Table 1

Chemical data and formulae for meneghinite.

Chemical data is in wt\% (average of three spot analyses) and chemical formulae on the basis of $\Sigma(\mathrm{Pb}+\mathrm{Sb})=20$ atoms per formula unit (apfu).

\begin{tabular}{|c|c|c|c|c|c|c|c|}
\hline Element & Average & E.s.d. & Atom & Apfu & E.s.d. & $\begin{array}{l}\text { Probe } \\
\text { standard }\end{array}$ & $\begin{array}{l}\text { WDS } \\
\text { line }\end{array}$ \\
\hline $\mathrm{Cu}$ & 1.45 & 0.02 & $\mathrm{Cu}$ & 0.99 & 0.01 & $\mathrm{Cu}$ metal & $\mathrm{Cu} K \alpha$ \\
\hline $\mathrm{Ag}$ & 0.07 & 0.04 & $\mathrm{Ag}$ & 0.03 & 0.02 & Ag metal & $\operatorname{Ag} L \alpha$ \\
\hline $\mathrm{Pb}$ & 62.32 & 0.22 & $\mathrm{~Pb}$ & 13.07 & 0.01 & $\mathrm{PbS}$ & $\mathrm{Pb} M \alpha$ \\
\hline $\mathrm{Sb}$ & 19.40 & 0.09 & $\mathrm{Sb}$ & 6.93 & 0.03 & Stibnite & Sb $L \alpha$ \\
\hline $\mathrm{S}$ & 17.59 & 0.05 & $\mathrm{~S}$ & 23.85 & 0.15 & Pyrite & $\mathrm{S} K \alpha$ \\
\hline $\mathrm{Se}$ & 0.11 & 0.05 & $\mathrm{Se}$ & 0.06 & 0.03 & Se element & $\operatorname{Se} L \alpha$ \\
\hline Total & 100.94 & 0.23 & Ev† & 0.3 & 0.6 & & \\
\hline
\end{tabular}

$\dagger$ Relative error on valence equilibrium $(\%)$, calculated as $\left[\sum(\mathrm{val}+)-\sum(\mathrm{val}-)\right]$ $\times 100 / \sum($ val- $)$.

Quantitative chemical analyses of meneghinite from the Bottino mine were carried out using a CAMECA SX100 electron microprobe (Microsonde Ouest laboratory, IFREMER, Plouzané, France). The operating conditions were: accelerating voltage $20 \mathrm{kV}$, beam current $20 \mathrm{nA}$, beam size $\simeq 1 \mu \mathrm{m}$. The studied grain was very homogeneous $(n=3)$. Chemical data are given in Table 1. Compared with the ideal formula of $\mathrm{CuPb}_{13} \mathrm{Sb}_{7} \mathrm{~S}_{24}$, the chemical formula of the meneghinite from the Bottino mine in Italy is $\left(\mathrm{Cu}_{0.99} \mathrm{Ag}_{0.03}\right)_{\Sigma 1.02} \mathrm{~Pb}_{13.07} \mathrm{Sb}_{6.93}\left(\mathrm{~S}_{23.85} \mathrm{Se}_{0.06}\right)_{\Sigma 23.91}$.

\subsection{Single-crystal X-ray diffraction study}

The intensity data were collected from a meneghinite crystal (size: $0.14 \times 0.07 \times 0.06 \mathrm{~mm}$ ), obtained by crushing a piece of a larger crystal, using a Rigaku (Oxford Diffraction) SuperNova single-crystal diffractometer equipped with an Atlas S2 CCD detector utilizing Mo $K \alpha$ radiation, which was provided by a microfocus X-ray tube and monochromated by primary mirror optics. The $\omega$ rotational scans (frame width $1.0^{\circ}$, counting time 150 seconds per frame) were adopted for the acquisition of the three-dimensional intensity data. From the total of 70366 reflections, 6604 were independent and 4696 classified as unique observed with $I>3 \sigma(I)$. Among these, 1473 were main reflections, 2577 first-order satellites, and 2554 second-order satellites. Corrections for background, Lorentz effects and polarization were applied during data reduction in CrysAlis software; a correction for absorption, using Gaussian integration $\left(\mu=54.56 \mathrm{~mm}^{-1}\right)$, was applied in JANA2006 (Petř́ćcek et al., 2014) to the data leading to $R_{\text {int }}=0.045$. Table 2 shows the experimental details.

\subsection{Superspace structure refinement}

All calculations related to the structure refinement have been performed with the JANA2006 system of programs (Petříček et al., 2014). The experimental data collection obtained at room temperature revealed systematic extinctions unequivocally defining the Pnma(0 $\beta 0) 00$ s superspace group. As the meneghinite structure is well known, we used the fractional coordinates of atoms reported by Moëlo et al. (2002) as a starting model in our refinement. The refinement of the
Table 2

Experimental details.

\begin{tabular}{|c|c|}
\hline \multicolumn{2}{|l|}{ Crystal data } \\
\hline Chemical formula & $\mathrm{CuPb}_{13} \mathrm{Sb}_{7} \mathrm{~S}_{24}$ \\
\hline$M_{\mathrm{r}}$ & 4393.3 \\
\hline Cell setting, superspace group & Orthorhombic, Pnma $(0 \beta 0) 00$ s \\
\hline Temperature $(\mathrm{K})$ & 297 \\
\hline Wavevector & $\mathbf{q}=0.5433(4) \mathbf{b}^{*}$ \\
\hline$a, b, c(\AA)$ & $24.0549(3), 4.1291(6), 11.3361$ (16) \\
\hline$V\left(\AA^{3}\right)$ & $1126.0(2)$ \\
\hline$Z$ & 1 \\
\hline Radiation type & Mo $K \alpha$ \\
\hline$\mu\left(\mathrm{mm}^{-1}\right)$ & 54.69 \\
\hline \multicolumn{2}{|l|}{ Data collection } \\
\hline Diffractometer & $\begin{array}{l}\text { SuperNova Rigaku } \\
\text { (Oxford Diffraction) }\end{array}$ \\
\hline $\begin{array}{l}\text { No. of measured, independent and } \\
\text { observed }[I>3 \sigma(I)] \text { reflections }\end{array}$ & $70366,6604,4696$ \\
\hline No. of main reflections & 1473 \\
\hline $\begin{array}{l}\text { No. of first-order satellite } \\
\text { reflections }\end{array}$ & 2577 \\
\hline $\begin{array}{l}\text { No. of second-order satellite } \\
\text { reflections }\end{array}$ & 2554 \\
\hline$R_{\text {int }}$ & 0.045 \\
\hline \multicolumn{2}{|l|}{ Refinement } \\
\hline Refinement on & $F^{2}$ \\
\hline$R, w R$ (all reflections) & $0.0479,0.1076$ \\
\hline$R, w R$ (main reflections) & $0.0252,0.0622$ \\
\hline \multicolumn{2}{|l|}{$R, w R$ (satellites) } \\
\hline First order & $0.0490,0.0979$ \\
\hline Second order & $0.1725,0.3047$ \\
\hline$S$ & 1.197 \\
\hline No. of reflections & 6604 \\
\hline No. of parameters & 216 \\
\hline$\Delta \rho_{\max }, \Delta \rho_{\min }\left(\mathrm{e} \AA^{-3}\right)$ & $1.66,-1.58$ \\
\hline Extinction correction & None \\
\hline Source of atomic scattering factors & $\begin{array}{l}\text { International Tables for Crystallo- } \\
\quad \text { graphy (Wilson, 1992) }\end{array}$ \\
\hline
\end{tabular}

Computer programs: JANA2006 (Petříček et al., 2014).

modulated structure was straightforward. The only problem encountered was the partially occupied position of the $\mathrm{Cu}$ atom as well as two mixed sites $\mathrm{Pb} 3 / \mathrm{Sb} 3$ and $\mathrm{Pb} 5 / \mathrm{Sb} 5$. The occupational and substitutional modulation waves lead to an almost perfect separation of $\mathrm{Cu} /[]$ and $\mathrm{Pb} / \mathrm{Sb}$ positions. That was the reason why two modulation models were tested. One with a full use of crenel functions (Petříček et al., 1995, 2016) and a second based on harmonic functions. It turned out that the harmonic model leads to a significantly better fit. Therefore, it suggests that in the crystal there are $\mathrm{Pb}$-rich and $\mathrm{Sb}$ rich domains, but the boundaries between them are not sharp. The same mechanism is valid for regions where $\mathrm{Cu}$ atoms are present.

Positional parameters, occupational waves and atomic displacement parameters are given as supplementary tables. Bond distances are reported in Table 3.

\section{Results and discussion}

The average structure of meneghinite (Fig. 2) can be described as made up of (501) or (501) slices of SnS-like structure. The surface of these slices form wavy composition planes on which the two adjacent slices face each other and are mutually 
Table 3

Selected bond distances $(\AA)$ in the modulated structure of meneghinite.

\begin{tabular}{|c|c|c|c|}
\hline & Average & Minimal & Maximal \\
\hline $\mathrm{Cu} 1-\mathrm{S} 1^{\mathrm{ii}}$ & $2.41(8)$ & $2.39(13)$ & $2.45(13)$ \\
\hline $\mathrm{Cu} 1-\mathrm{S}^{\mathrm{iii}}$ & $2.36(8)$ & $2.29(9)$ & $2.52(9)$ \\
\hline $\mathrm{Cu} 1-\mathrm{S} 3$ & $2.37(8)$ & $2.29(9)$ & $2.52(9)$ \\
\hline $\mathrm{Cu} 1-\mathrm{S} 6$ & $2.42(9)$ & 2.29 (13) & $2.48(13)$ \\
\hline $\mathrm{Pb} 1-\mathrm{S} 1^{\mathrm{iii}}$ & $2.988(3)$ & $2.949(4)$ & $3.042(4)$ \\
\hline $\mathrm{Pb} 1-\mathrm{S} 1$ & $2.988(3)$ & $2.949(4)$ & $3.042(4)$ \\
\hline $\mathrm{Pb} 1-\mathrm{S}^{\mathrm{iv}}$ & $2.939(3)$ & $2.859(4)$ & $2.987(4)$ \\
\hline $\mathrm{Pb} 1-\mathrm{S}^{\mathrm{v}}$ & $2.939(3)$ & $2.859(4)$ & $2.987(4)$ \\
\hline $\mathrm{Pb} 1-\mathrm{S}^{\mathrm{iv}}$ & $2.901(4)$ & $2.891(6)$ & $2.907(6)$ \\
\hline $\mathrm{Pb} 1-\mathrm{S3}^{\mathrm{x}}$ & 3.319 (4) & $3.163(6)$ & $3.430(6)$ \\
\hline $\mathrm{Pb} 1-\mathrm{S} 6$ & $3.148(4)$ & $3.095(7)$ & $3.208(7)$ \\
\hline $\mathrm{Pb} 2-\mathrm{S} 1$ & $2.587(3)$ & $2.445(6)$ & $2.673(6)$ \\
\hline $\mathrm{Pb} 2-\mathrm{S}^{\mathrm{iv}}$ & $3.044(4)$ & $2.890(5)$ & $3.342(5)$ \\
\hline $\mathrm{Pb} 2-\mathrm{S}_{4}^{\mathrm{v}}$ & $3.045(4)$ & $2.890(5)$ & $3.337(5)$ \\
\hline $\mathrm{Pb} 2-\mathrm{S} 5$ & $2.802(4)$ & $2.496(4)$ & $2.983(4)$ \\
\hline $\mathrm{Pb} 2-\mathrm{S}^{\mathrm{vi}}$ & $2.803(4)$ & $2.490(4)$ & $2.983(4)$ \\
\hline $\mathrm{Pb} 2-\mathrm{S} 4^{\text {viii }}$ & $3.503(3)$ & 3.489 (6) & $3.527(6)$ \\
\hline $\mathrm{Sb} 2-\mathrm{S} 1$ & $2.529(3)$ & $2.411(6)$ & $2.660(6)$ \\
\hline $\mathrm{Sb} 2-\mathrm{S} 5$ & $2.684(4)$ & $2.427(4)$ & $2.982(4)$ \\
\hline $\mathrm{Sb} 2-\mathrm{S}^{\mathrm{vi}}$ & $2.686(4)$ & $2.427(4)$ & $2.983(4)$ \\
\hline $\mathrm{Pb} 3-\mathrm{S} 2$ & $2.597(3)$ & $2.462(6)$ & $2.680(6)$ \\
\hline $\mathrm{Pb} 3-\mathrm{S}^{\mathrm{iv}}$ & $3.010(3)$ & $2.936(4)$ & 3.199 (4) \\
\hline $\mathrm{Pb} 3-\mathrm{S}^{\mathrm{v}}$ & $3.010(3)$ & $2.936(4)$ & $3.200(4)$ \\
\hline $\mathrm{Pb} 3-\mathrm{S}^{\mathrm{iii}}$ & $2.838(4)$ & $2.517(4)$ & $3.013(4)$ \\
\hline $\mathrm{Pb} 3-\mathrm{S} 4$ & $2.838(4)$ & $2.520(4)$ & $3.013(4)$ \\
\hline $\mathrm{Pb} 3-\mathrm{S}^{\mathrm{i}}$ & 3.489 (4) & $3.458(7)$ & $3.514(7)$ \\
\hline $\mathrm{Sb} 3-\mathrm{S} 2$ & $2.544(3)$ & $2.438(6)$ & $2.665(6)$ \\
\hline $\mathrm{Sb} 3-\mathrm{S} 4^{\mathrm{iii}}$ & $2.717(4)$ & $2.452(4)$ & $2.993(4)$ \\
\hline $\mathrm{Sb} 3-\mathrm{S} 4$ & $2.717(4)$ & $2.452(4)$ & $2.994(4)$ \\
\hline $\mathrm{Pb} 4-\mathrm{S} 1^{\mathrm{iii}}$ & $3.037(3)$ & $2.890(4)$ & 3.137 (4) \\
\hline $\mathrm{Pb} 4-\mathrm{S} 1$ & $3.037(3)$ & 2.890 & $3.136(4)$ \\
\hline $\mathrm{Pb} 4-\mathrm{S}^{\mathrm{vii}}$ & $2.948(4)$ & 2.830 & $3.076(4)$ \\
\hline $\mathrm{Pb} 4-\mathrm{S}^{\text {viii }}$ & $2.947(4)$ & $2.830(4)$ & $3.076(4)$ \\
\hline $\mathrm{Pb} 4-\mathrm{S} 5$ & $2.893(4)$ & $2.843(6)$ & $2.953(6)$ \\
\hline $\mathrm{Pb} 4-\mathrm{S}^{\mathrm{x}}$ & $3.811(4)$ & $3.536(6)$ & $3.964(6)$ \\
\hline $\mathrm{Pb} 4-\mathrm{S}^{\mathrm{xi}}$ & $3.291(4)$ & $3.076(5)$ & $3.481(5)$ \\
\hline $\mathrm{Pb} 4-\mathrm{S}^{\mathrm{x}}$ & $3.290(4)$ & $3.076(5)$ & $3.481(5)$ \\
\hline $\mathrm{Pb} 5-\mathrm{S} 3$ & $2.519(4)$ & $2.429(6)$ & $2.596(6)$ \\
\hline $\mathrm{Pb} 5-\mathrm{S}^{\mathrm{i}}$ & $3.047(4)$ & $2.894(5)$ & $3.284(5)$ \\
\hline $\mathrm{Pb} 5-\mathrm{S}^{\mathrm{ix}}$ & $3.045(4)$ & $2.894(5)$ & $3.280(5)$ \\
\hline $\mathrm{Pb} 5-\mathrm{S} 6$ & $2.781(4)$ & $2.532(5)$ & $2.996(5)$ \\
\hline $\mathrm{Pb} 5-\mathrm{S6}^{\mathrm{vi}}$ & $2.780(4)$ & $2.529(5)$ & $2.996(5)$ \\
\hline $\mathrm{Pb} 5-\mathrm{S}^{\mathrm{v}}$ & $3.464(4)$ & $3.429(6)$ & $3.505(6)$ \\
\hline $\mathrm{Sb} 5-\mathrm{S} 3$ & $2.481(4)$ & $2.419(6)$ & $2.596(6)$ \\
\hline Sb5-S6 & $2.658(4)$ & $2.411(5)$ & $2.996(5)$ \\
\hline $\mathrm{Sb} 5-\mathrm{S}^{\mathrm{vi}}$ & $2.658(4)$ & $2.411(5)$ & $2.996(5)$ \\
\hline
\end{tabular}

Symmetry codes: (i) $x, y, z-1$; (ii) $-x+\frac{1}{2},-y+1, z-\frac{1}{2}$; (iii) $x, y-1, z$; (iv) $-x, y-\frac{1}{2},-z$; (v) $-x, y+\frac{1}{2},-z$; (vi) $x, y+1, z$; (vii) $x, y-1, z+1$; (viii) $x, y, z+1$; (ix) $x, y+1, z-1$; (x) $-x+\frac{1}{2},-y+1, z+\frac{1}{2}$; (xi) $-x+\frac{1}{2},-y, z+\frac{1}{2}$.

related by an $n$-glide plane parallel to (010) of meneghinite. Tetrahedral coordination sites in the wavy interface can be occupied by $\mathrm{Cu}$ atoms according to the coupled substitution $\mathrm{Cu}^{+}+\mathrm{Pb}^{2+} \rightarrow[]+\mathrm{Sb}^{3+}$.

In the structure there are six metal sites, $\mathrm{Cu}$ and $\mathrm{Pb} 1$ to $\mathrm{Pb} 5$, and six $\mathrm{S}$ atoms ( $\mathrm{S} 1$ to $\mathrm{S} 6$ ). The $\mathrm{Cu}$ position is partially occupied, $\mathrm{Pb} 1$ and $\mathrm{Pb} 4$ are fully occupied by $\mathrm{Pb}$ and $\mathrm{Pb} 2, \mathrm{~Pb} 3$ and $\mathrm{Pb} 5$ show variable $\mathrm{Sb}$ contents replacing $\mathrm{Pb}$. The most relevant variations observed as a function of the fourth $(t)$ coordinate in superspace concern the $\mathrm{Cu}$ and $\mathrm{Pb} 2, \mathrm{~Pb} 3$, and $\mathrm{Pb} 5$ polyhedra. The $\mathrm{Cu}$ position shows a strong occupation modulation (Fig. 3), almost bimodal, with regions where the corresponding polyhedron is empty $(\mathrm{Cu}$ has been refined versus structural vacancy). This reflects very well on the variation of bond distances as a function of the fourth coordinate in superspace, which range from $2.32 \AA$ ( Cu-rich regions) to $2.49 \AA$ (Cu-poor regions). It is noteworthy that we observed an almost regular alternation along the $b$ axis of large and small tetrahedra (Fig. 4a). The occupation modulation observed for $\mathrm{Pb} 2$ (refined versus $\mathrm{Sb}$ ) points to regions almost totally enriched in $\mathrm{Sb}$ at $t \sim 0.35$ (Fig. $5 a$ ). The corresponding bond distances (Fig. $5 b$ ) and bond valence sums (BVS; Fig. 5c), which show a jump to about 4.6 valence units (v.u.) from the value of 2.00 v.u., are in excellent agreement with this site distribution (in particular the value of 4.6 v.u. and in general the value of $>3.0$ v.u. have to be considered for $\mathrm{Pb}^{2+}$ atoms in an essentially $\mathrm{Sb}^{3+}$-dominated polyhedron). Indeed, at $t \sim 0.35$, three $M 2-\mathrm{S}$ bonds show a shortening to a mean bond distances of $2.63 \AA$ and two $M 2-\mathrm{S}$ bonds are too long to be considered still bonded to $M 2$ (Fig. $5 b$ ). This feature can be

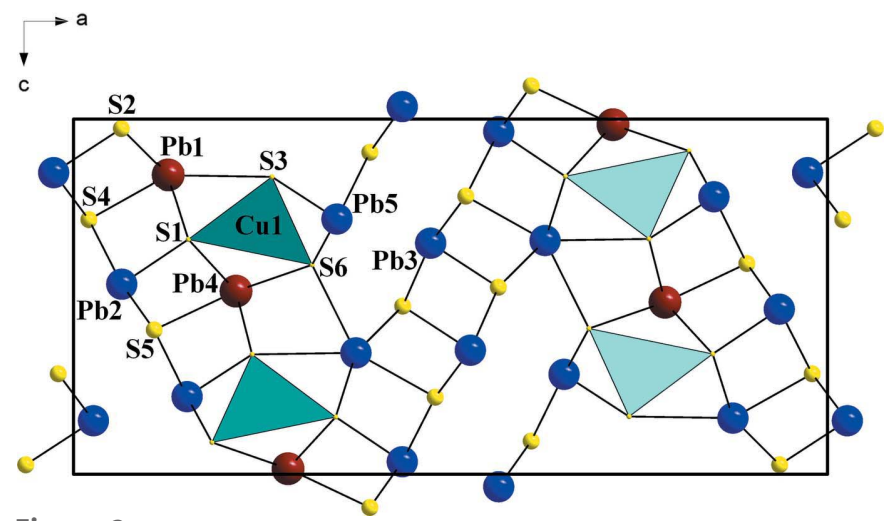

Figure 2

The average structure of meneghinite down [010]. Cu atoms are drawn as light-blue tetrahedra. Red, blue and yellow spheres correspond to $\mathrm{Pb}, \mathrm{Pb} /$ $\mathrm{Sb}$ and $\mathrm{S}$ atoms, respectively. The unit cell and the orientation of the figure are outlined.

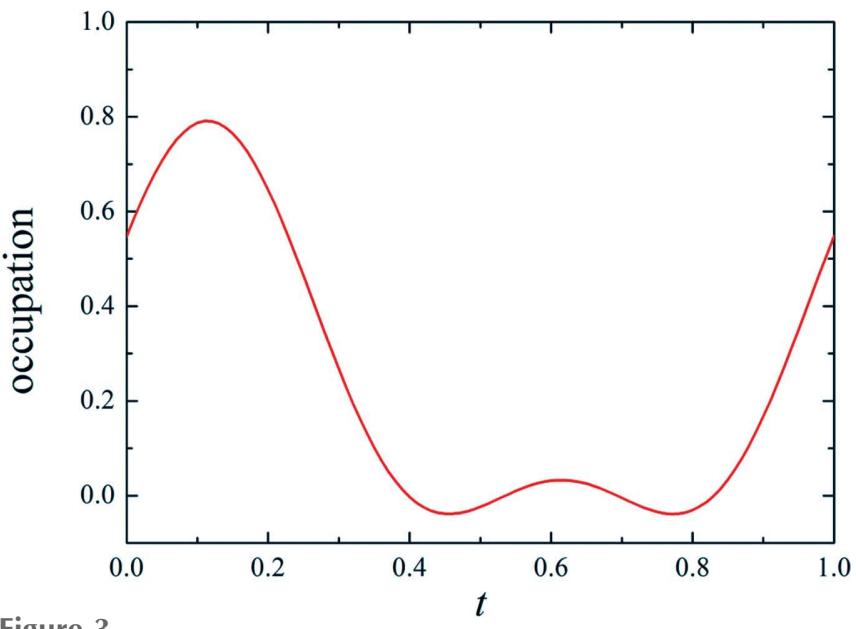

Figure 3

Occupation modulation of the $\mathrm{Cu}$ atom as a function of the fourth coordinate $(t)$ in superspace. Refined cation population at the site: $\mathrm{Cu}_{0.24}[]_{0.76}$. 
observed in Fig. 4(b) where two consecutive $\mathrm{Pb} 2 / \mathrm{Sb} 2$ atoms in the modulated structure of meneghinite are seen along the $b$ axis. Such an environment is characteristic for the stereochemical activity of the lone pair of electrons of $\mathrm{Sb}^{3+}$ atoms, which usually give rise to $(3+2)$-coordination polyhedra in sulfosalts (e.g. Ferraris et al., 2008). Similar considerations can be made for $\mathrm{Pb} 3$ (refined versus $\mathrm{Sb}$ ), which shows regions almost totally enriched in $\mathrm{Sb}$ at $t \sim 0.62$ (Fig. 6a), with corresponding shorter bond distances (Fig. $6 b$ ) and higher BVS (Fig. 6c). The only slight difference of the $\mathrm{Pb} 3$ position with respect to $\mathrm{Pb} 2$ is related to a more regular distribution of the bond distances when the polyhedra are dominated by lead
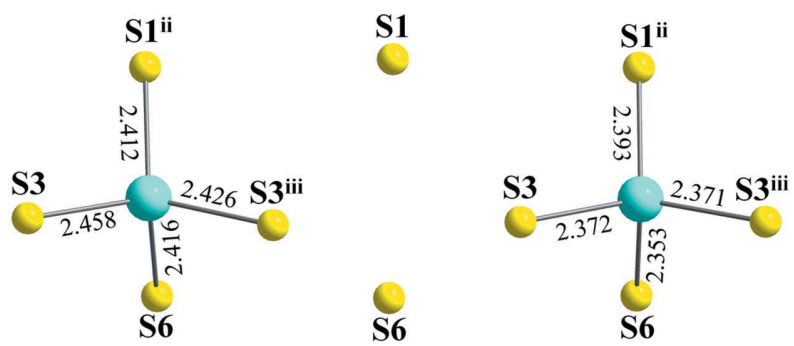

(a)

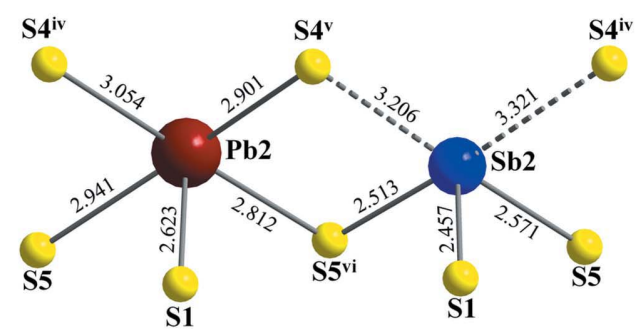

(b)

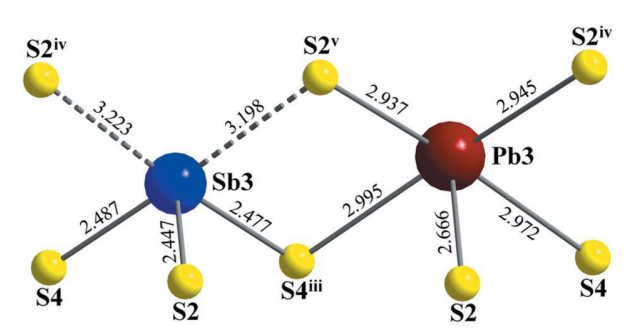

(c)

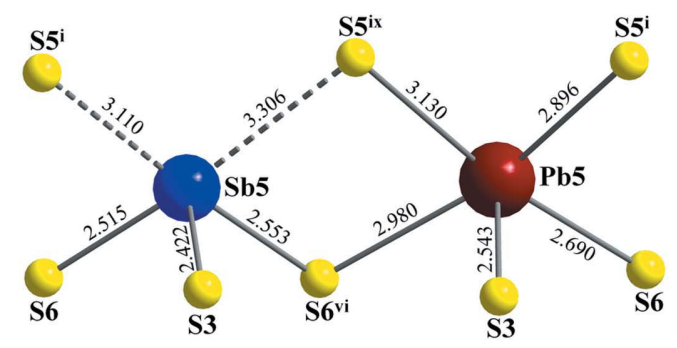

(d)

Figure 4

Coordination environments of $\mathrm{Cu} 1(a), \mathrm{Pb} 2 / \mathrm{Sb} 2(b), \mathrm{Pb} 3 / \mathrm{Sb} 3(c)$ and $\mathrm{Pb} 5 /$ Sb5 $(d)$ along the $b$ axis in the modulated structure of meneghinite. Atom colours as in Fig. 2. The $b$ axis is horizontal. Bond distances are given in $\AA$ A.
(Fig. 4c). More complex is the behavior of $\mathrm{Pb} 5$, which is the structural site with the higher concentration of $\mathrm{Sb}$. The Sb-for$\mathrm{Pb}$ substitution (Fig. $7 a$ ) seems to show a bimodal distribution as a function of the fourth coordinate in the superspace, with $\mathrm{Pb}$ enrichments in the $t$ range of $0.10-0.60$. To some extent, it resembles what is observed for the $\mathrm{Cu}$ modulation, but it is shifted along $t$. Indeed, we observed an almost regular alternation along the $b$ axis of $\mathrm{Pb}$ - and $\mathrm{Sb}$-dominated polyhedra in the modulated structure (Fig. $4 d$ ). The variation of the $M 5-\mathrm{S}$ bond distances (Fig. 7b) and of BVS (Fig. 7c) agrees well with the $\mathrm{Pb} / \mathrm{Sb}$ distribution at the site, with shorter bonds and higher BVS where $\mathrm{Sb}$ is the dominant cation. Pb1 (Fig. 8) and $\mathrm{Pb} 4$ (Fig. 9), fully occupied by $\mathrm{Pb}$, exhibit more regular polyhedra as a function of the fourth coordinate in superspace, and their BVS are always close to 2.00 v.u.

The general structural characteristics described above indicate that the driving forces stabilizing the modulated

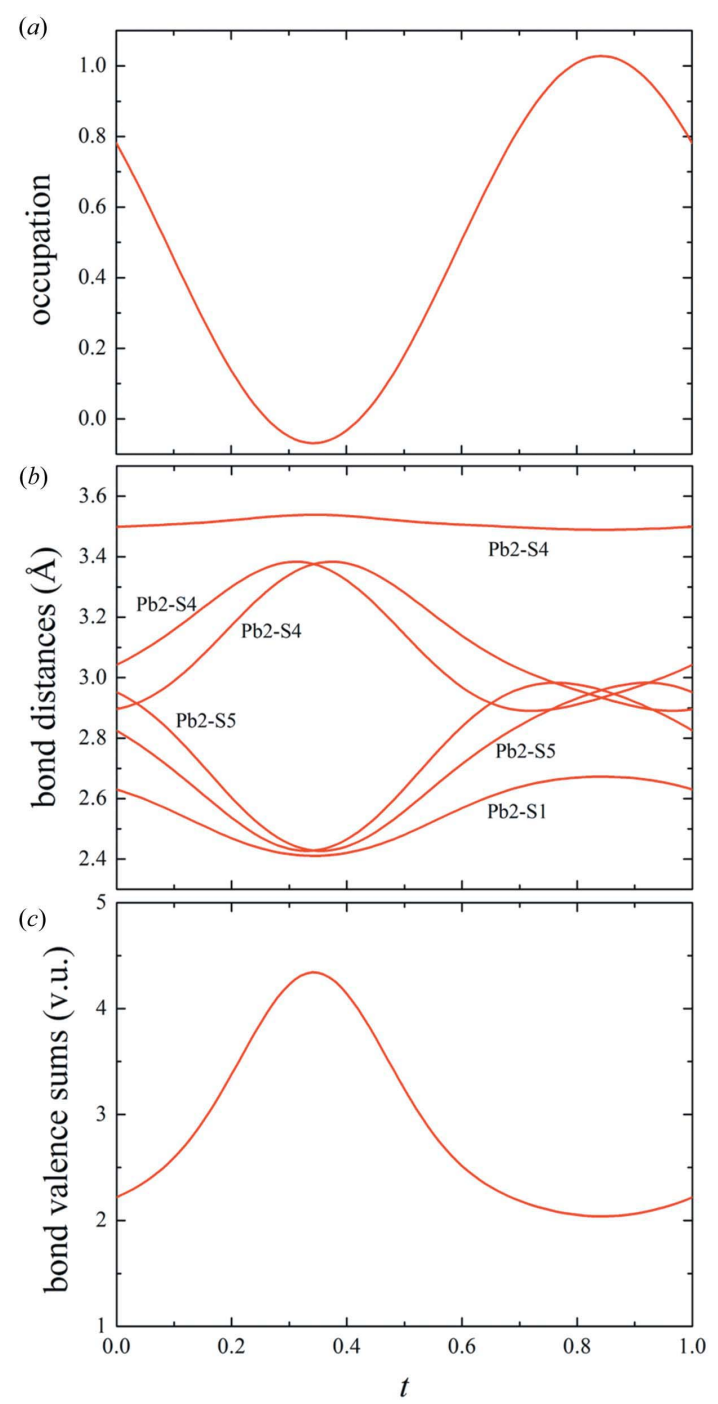

Figure 5

Occupation modulation $(a)$, bond distances $(b)$ and bond valence sums (c) of the $\mathrm{Pb} 2 / \mathrm{Sb} 2$ atom as a function of the fourth coordinate $(t)$ in superspace. Values $>3.0$ v.u. have to be considered for $\mathrm{Pb}^{2+}$ atoms in essentially $\mathrm{Sb}^{3+}$-dominated polyhedra. Refined cation population at the site: $\mathrm{Pb}_{0.48} \mathrm{Sb}_{0.52}$. 
structure of meneghinite are linked to the occupational modulation of $\mathrm{Cu}$ and some of the $\mathrm{Pb}$ atoms. Especially interesting is what happens to the $\mathrm{Pb}$ atoms when replaced by $\mathrm{Sb}$. The considerable difference in size between $\mathrm{Pb}^{2+}$ and $\mathrm{Sb}^{3+}$ [although we are dealing with a highly covalent structure with very asymmetric coordinations, for the sake of clarity we compare the ionic radii of $\mathrm{Pb}^{2+}=1.19$ and $\mathrm{Sb}^{3+}=0.76 \AA$; values taken from Shannon (1976)] provokes a continuous change in the coordination polyhedra as a function of the fourth coordinate in superspace (Fig. 4), which causes the presence of three- to sixfold coordinations of the $M$ cations $(\mathrm{Pb} / \mathrm{Sb})$ in different portions of the modulated structure. Although the change in coordination is clearly evident (Fig. 4), the deformation of the structure is not marked, as the modulation in meneghinite mainly involves the occupation of the structural sites, with minor effects on the positions of the
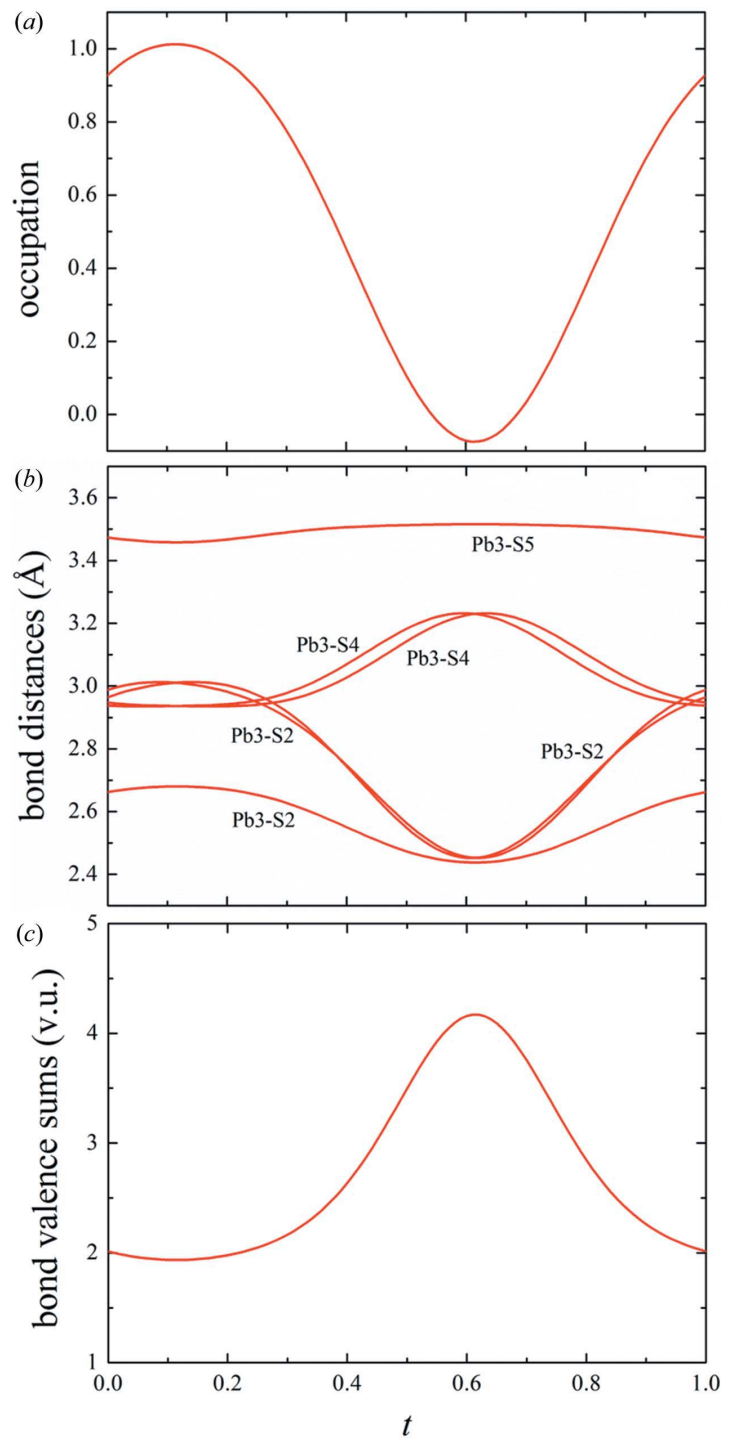

Figure 6

Occupation modulation $(a)$, bond distances $(b)$ and bond valence sums (c) of the $\mathrm{Pb} 3 / \mathrm{Sb} 3$ atom as a function of the fourth coordinate $(t)$ in superspace. Values $>3.0$ v.u. have to be considered for $\mathrm{Pb}^{2+}$ atoms in essentially $\mathrm{Sb}^{3+}$-dominated polyhedra. Refined cation population at the site: $\mathrm{Pb}_{0.52} \mathrm{Sb}_{0.48}$. atoms and their atomic displacement parameters. The almost bimodal and similar distribution of the occupation of $\mathrm{Cu} /[]$ and $\mathrm{Pb} / \mathrm{Sb}$ at $M 5$ is in agreement with the hypothesized coupled substitution $\mathrm{Sb}^{3+}+[] \rightarrow \mathrm{Pb}^{2+}+\mathrm{Cu}^{+}$(Moëlo et al., 2002), which shows the reason for the incorporation of copper in the meneghinite structure.

\section{Outlook}

The introduction of area detectors in the 1990s has brought some revolutionary improvements into the data collection time, ease of diffractometer operation, and sensitivity. Furthermore, the recent availability of very powerful CCD detectors and software has brought a significant revolution into aperiodic crystallography, enabling researchers to work with very small samples having complicated structures

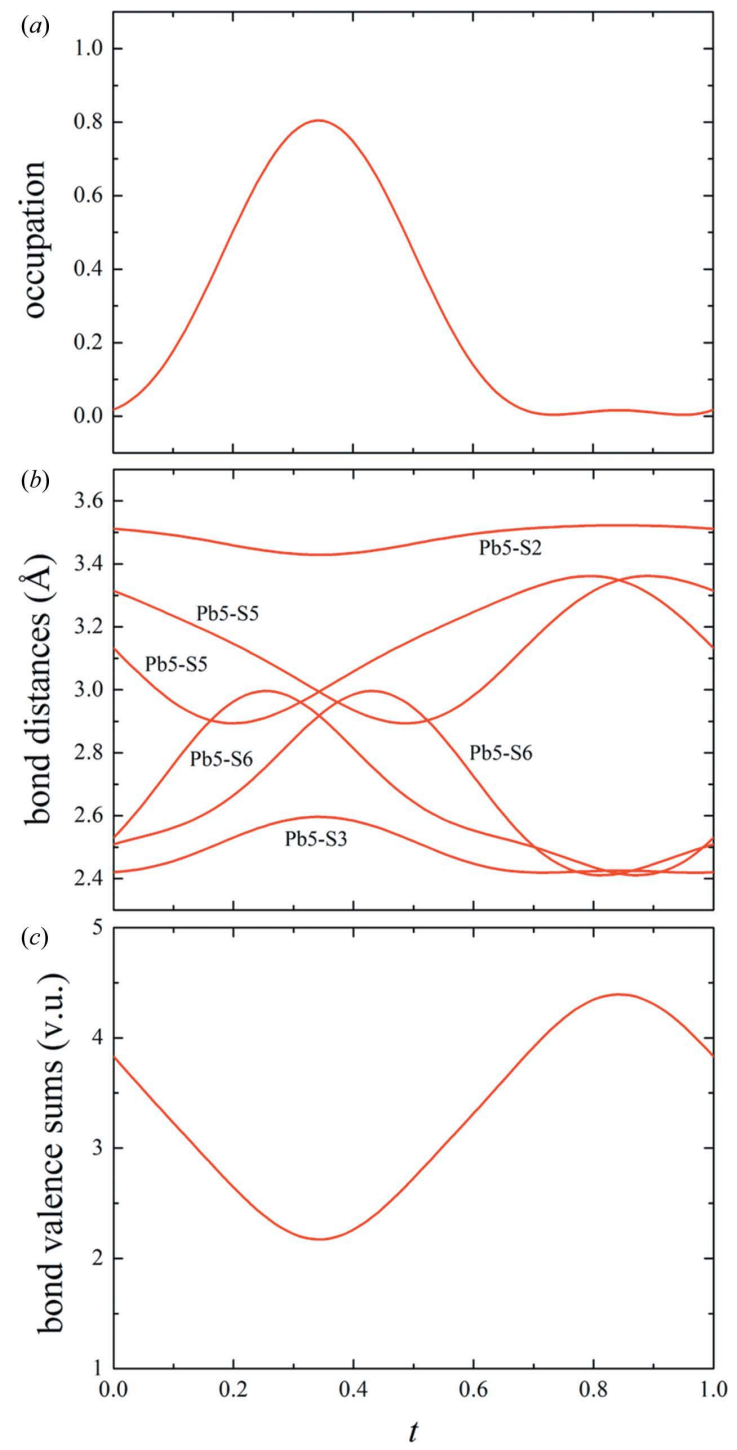

Figure 7

Occupation modulation $(a)$, bond distances $(b)$ and bond valence sums (c) of the $\mathrm{Pb} 5 / \mathrm{Sb} 5$ atom as a function of the fourth coordinate $(t)$ in superspace. Values $>3.0$ v.u. have to be considered for $\mathrm{Pb}^{2+}$ atoms in essentially $\mathrm{Sb}^{3+}$-dominated polyhedra. Refined cation population at the site: $\mathrm{Pb}_{0.28} \mathrm{Sb}_{0.72}$. 
(Chapuis \& Arakcheeva, 2013; Pina \& López-Acevedo, 2016). Unfortunately, all these great advantages have been accompanied by a turning of the diffractometer more into a black box that operates in a push-button mode. This mode usually works very well with most of the periodic inorganic structures, but it is definitely not adequate for experiments involving samples exhibiting incommensurate structures. For this reason, several incommensurate structures belonging to the mineral kingdom could have been inadequately characterized, or, much more likely, been considered commensurate even if they were not. A very clever example of the procedure that should be followed for complex cases is that adopted by Petříček \& Makovicky (2006) for the study of selected members (gladite, salzburgite, paarite and krupkaite) of the bismuthinite-aikinite $\left.\left(\mathrm{Bi}_{2} \mathrm{~S}_{3}-\mathrm{CuPbBiS}\right)_{3}\right)$ series. Although these structures are real superstructures, they were refined as commensurately modulated structures using the superspace approach in the superspace group $\operatorname{Pmcn}(0 \beta 0) 00$ s with $\beta$ assuming the value of $\frac{1}{3}, \frac{1}{4}, \frac{1}{5}$ and 2 . The case of meneghinite presented here is a clear example of how a complex incommensurate structure was considered a commensurate one (e.g. Euler \& Hellner, 1960; Hicks \& Nuffield, 1978). An eventual refinement of the 'forced' commensurate structure, would have not allowed (i) the understanding of the real driving forces causing the appearance of the observed satellite reflections, (ii) the actual global adjustments of the structure framework, and (iii) the overall positional (or displacement, occupancy) trends, which remain usually submerged in localized descriptions. Similar problems could be encountered if

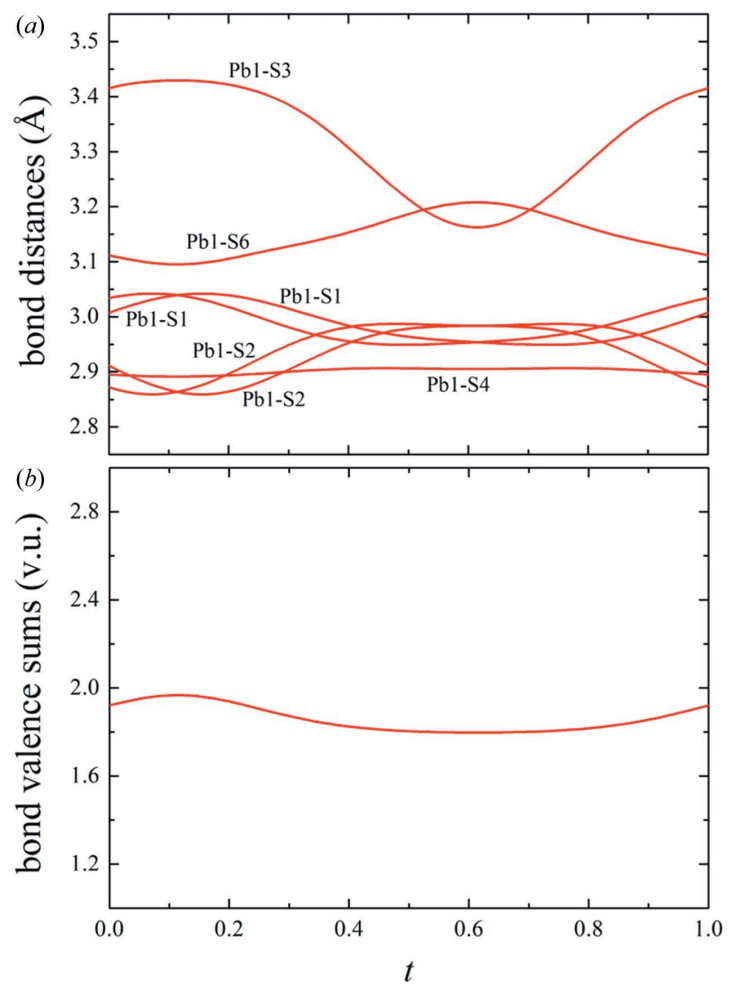

Figure 8

Bond distances $(a)$ and bond valence sums $(b)$ of the $\mathrm{Pb} 1$ atom as a function of the fourth coordinate $(t)$ in superspace. one had refined meneghinite as an elevenfold commensurate superstructure [given the fact that $6 / 11=0.5454$, very close to the incommensurate component of the modulation wavevector along $\mathbf{b}^{*}$, i.e. 0.5433 (4)] in three-dimensional physical space. The superspace approach is indeed intended to allow the study of the continuous variations of a modulated structure as a function of the additional dimensions in the superspace and reveal the global adjustments of the structure framework.

\section{Acknowledgements}

This research received support by the University of Florence, 'Progetto di Ateneo 2014' issued to LB and by MIUR through project SIR 2014 'THALMIGEN - Thallium: Mineralogy, Geochemistry, and Environmental Hazards' granted to CB. The crystallographic part was supported by the project 1403276S of the Czech Science Foundation using instruments of the ASTRA Lab established within the Operation program Prague Competitiveness - project CZ.2.16/3.1.00/24510. Thoughtful comments by Emil Makovicky and two anonymous reviewers were very helpful to improve the quality of the paper.

\section{Funding information}

Funding for this research was provided by: University of Florence, 'Progetto di Ateneo 2014'; Ministero dell'Istruzione, dell'Università e della Ricerca (award No. SIR 2014 Grant No.

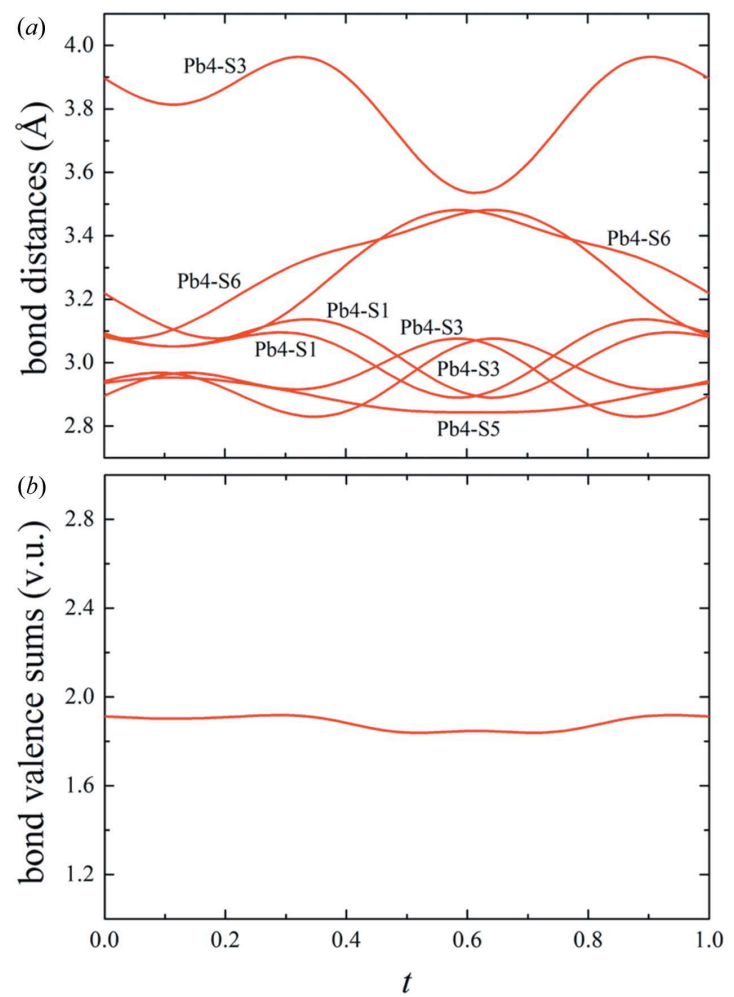

Figure 9

Bond distances $(a)$ and bond valence sums $(b)$ of the $\mathrm{Pb} 4$ atom as a function of the fourth coordinate $(t)$ in superspace. 
RBSI14A1CV); Czech Science Foundation (award No. 1403276S).

\section{References}

Angel, R. J., Gatta, G. D., Ballaran, T. B. \& Carpenter, M. (2008). Can. Mineral. 46, 1465-1476.

Angel, R. J., McMullan, R. K. \& Prewitt, C. T. (1991). Am. Mineral. 76, 332-342.

Bechi, E. (1852). Atti R. Accad. Georg. 30, 84-87. (In Italian.)

Bindi, L. (2008). Philos. Mag. Lett. 88, 533-541.

Bindi, L., Bonazzi, P., Dušek, M., Petř́íček, V. \& Chapuis, G. (2001). Acta Cryst. B57, 739-746.

Bindi, L., Dusek, M., Petricek, V. \& Bonazzi, P. (2006). Acta Cryst. B62, 1031-1037.

Bindi, L., Schaper, A. K., Kurata, H. \& Menchetti, S. (2013). Am. Mineral. 98, 1279-1284.

Bolotina, N. B. (2006). Crystallogr. Rep. 51, 968-976.

Bolotina, N. B., Rastsvetaeva, R. K., Chapuis, G., Schönleber, A., Sapozhnikov, A. N. \& Kashaev, A. A. (2004). Ferroelectrics, 305, 95-98.

Bolotina, N. B., Rastsvetaeva, R. K. \& Sapozhnikov, A. N. (2006). Crystallogr. Rep. 51, 589-595.

Bolotina, N. B., Rastsvetaeva, R. K., Sapozhnikov, A. N., Kashaev, A. A., Shönleber, A. \& Chapuis, G. (2003a). Crystallogr. Rep. 48, 721-727.

Bolotina, N. B., Rastsvetaeva, R. K., Sapozhnikov, A. N., Kashaev, A. A., Schöenleber, A. \& Chapuis, G. (2003b). Crystallogr. Rep. 48, 8-11.

Buseck, P. R. \& Cowley, J. M. (1983). Am. Mineral. 68, 18-40.

Caracas, R. \& Gonze, X. (2001). Acta Cryst. B57, 633-637.

Chapman, E. J. (1843). Practical Mineralogy, p. 127. London: Hippolyte Bailliere.

Chapuis, G. \& Arakcheeva, A. (2013). R. Fis. Acc. Lincei, 24, 77 84.

Euler, R. \& Hellner, E. (1960). Z. Kristallogr. 113, 345-372.

Evain, M., Petricek, V., Moëlo, Y. \& Maurel, C. (2006). Acta Cryst. B62, 775-789.

Ferraris, G., Makovicky, E. \& Merlino, S. (2008). Crystallography of Modular Materials. Oxford University Press, 370 pp.

Friese, K., Grzechnik, A., Petříček, V., Schönleber, A., van Smaalen, S. \& Morgenroth, W. (2011). Acta Cryst. B67, 18-29.

Hassan, I. (2000). Am. Mineral. 85, 1383-1389.

Hassan, I., Antao, S. M. \& Parise, J. B. (2004). Mineral. Mag. 68, 499513.

Hassan, I. \& Buseck, P. R. (1989). Am. Mineral. 74, 394-410.

Hassan, I. \& Buseck, P. R. (1992). Can. Mineral. 30, 49-59.

Heaney, P. J. \& Veblen, D. R. (1991). Am. Mineral. 76, 1018-1032.

Hicks, W. D. \& Nuffield, E. W. (1978). Can. Mineral. 16, 393-395.

Janssen, T., Chapuis, G. \& de Boissieu, M. (2007). Aperiodic Crystals, from Modulated Phases to Quasicrystals. Oxford University Press.
Kalning, M., Dorna, V., Press, W., Kek, S. \& Boysen, H. (1997). Z. Kristallogr. 212, 545-549.

Krutzen, B. C. H. \& Inglesfield, J. E. (1990). J. Phys. Condens. Matter, 2, 4829-4847.

Li, F. \& Franzen, H. F. (1996). J. Solid State Chem. 126, 108-120.

Makovicky, E. (1985). Fortschr. Miner. 63, 45-89.

Makovicky, E. (1997). EMU Notes Mineral. 1, 237-271.

Makovicky, E. \& Hyde, B. G. (1981). Struct. Bond. 46, 103-105.

Makovicky, E., Leonardsen, E. \& Moëlo, Y. (1994). Neues Jahr. Miner. Abh. 166, 169-191.

Makovicky, E., Petř́čcek, V., Dušek, M. \& Topa, D. (2008). Am. Mineral. 93, 1787-1798.

Makovicky, E., Petř́ícek, V., Dušek, M. \& Topa, D. (2011). Am. Mineral. 96, 1686-1702.

Moëlo, Y., Palvadeau, P., Meisser, N. \& Meerschaut, A. (2002). C. R. Geosci. 334, 529-536.

Petříček, V., Dušek, M. \& Palatinus, L. (2014). Z. Kristallogr. 229, 345-352.

Petř́iček, V., Eigner, V., Dušek, M. \& Čejchan, A. (2016). Z. Kristallogr. 231, 301-312.

Petříček, V. \& Makovicky, E. (2006). Can. Mineral. 44, 189-206.

Petř́íček, V., van der Lee, A. \& Evain, M. (1995). Acta Cryst. A51, 529-535.

Pina, C. M. \& López-Acevedo, V. (2016). Crystals, 6, 137.

Pring, A., Williams, T. \& Withers, R. (1993). Am. Mineral. 78, 619626.

Pryde, A. K. A. \& Dove, M. T. (1998). Phys. Chem. Miner. 26, 171179.

Rastsvetaeva, R. K., Bolotina, N. B., Sapozhnikov, A. N., Kashaev, A. A., Schoenleber, A. \& Chapuis, G. (2002). Crystallogr. Rep. 47, 404-407.

Sakamoto, S., Shimobayashi, N. \& Kitamura, M. (2003). Am. Mineral. 88, $1605-1607$.

Sanchez-Munoz, L., Nistor, L., Van Tendeloo, G. \& Sanz, J. (1998). J. Electron Microsc. 47, 17-28.

Schutte, W. J. \& de Boer, J. L. (1988). Acta Cryst. B44, 486-494.

Schutte, W. J. \& de Boer, J. L. (1993). Acta Cryst. B49, 398-403.

Shannon, R. D. (1976). Acta Cryst. A32, 751-767.

Smaalen, S. van (2007). Incommensurate Crystallography. Oxford University Press.

Steurer, W. \& Jagodzinski, H. (1988). Acta Cryst. B44, 344-351.

Subramanian, R. K., Muntean, L., Norcross, J. A. \& Ailion, D. C. (2000). Phys. Rev. B, 61, 996-1002.

Wilson, A. J. C. (1992). Editor. International Tables for X-ray Crystallography, Vol. C. Dordrecht: Kluwer Academic Publishers. Withers, R., Noren, L., Welberry, T., Bindi, L., Evain, M. \& Menchetti, S. (2008). Solid State Ionics, 179, 2080-2089.

Withers, R. L., Thompson, J. G., Melnitchenko, A. \& Palethorpe, S. R. (1998). Acta Cryst. B54, 547-557.

Xu, H. \& Veblen, D. R. (1995). Am. Mineral. 80, 87-93.

Yamamoto, A., Nakazawa, H., Kitamura, M. \& Morimoto, N. (1984). Acta Cryst. B40, 228-237. 